\title{
OUTCOME OF IN-VITRO FERTILIZATION AND THE AUTOANTIBODIES AGAINST ANNEXIN V AND CARDIOLIPIN
}

\author{
Aziza M. A. MANSOUR *, Ahmed M. A. Rammah* and \\ Hala M. T. EL-Mougy *** \\ * International Islamic Center For Population Studies \& Researches, Al Azhar University, Cairo. \\ **Biochemistry Department, Faculty of Medicine for Girls** Al Azhar University, Cairo
}

\section{ABSTRACT}

Objective: To evaluate the role of anti-annexin $\mathrm{V}$ antibodies (aAX) and anticardiolipin antibodies (ACA) as risk factors and predictors for in vitro fertilization-embryo transfer (IVF or ICSI) outcome.

Design: Prospective study.

Setting: IVF unit, Int. Islamic center for population studies and researches, Al-Azhar University, and Health centers in $10^{\text {th }}$ of Ramadan city.

Subjects and Methods: Were classified into 3 groups:-

Group I: 30 women had one or more failed IVF_ET despite good morphological quality of the transferred embryos.

Group II: 30 non-pregnant women had previous history of live births.

Group III: 30 pregnant women in the first trimester as controls previously delivered normally and no previous history of pregnancy loss. All were submitted to:

1) Detailed history to eliminate any case with renal, hepatic, or metabolic diseases.

2) Complete medical examination and laboratory investigations to exclude autoimmune disease, infecuon. hypertension, D.M., or other endocrinal disease.

3) a- Serum antiannexin $V$ antibodies were measured by Eliza.

b-Serum anticardiolipin antibodies were mensured by Eliza.

Results:

1) Serum antiannexin V IgG and serum anticardiolipin IgG were increased significantly in group I compared to the other groups.

2) There was no significant difference between group II\&III for both paraneters of antiannexin $V \operatorname{IgG} \&$ anticardiolipin IgG with lower level in group III than group II.

Conclusion: The antiannexin V IgG \& anticardiolipin IgG both can be used as predictors for IVF-ET success.

Key Words: Antiphospholipid antibodies (APA)s-antiannexin (aAN)-anticardiolipin (ACA)

\section{INTRODUCTION}

Anti-phospholipid antibodies (APA) are heterogeneous group of autoantibodies that target phospholipid or phospholipid-binding proteins. Their presence was shown to induce several thrombotic states, including idiopathic recurrent spontaneous abortions. (1)
Antiphospholipid antibodies (APA) are an established cause of recurrent pregnancy loss as defective embryonic implantation is a common link between unexplained infertility and recurrent miscarriage. Interest has been focussed on the potential relationship between antiphospholipid (APL) and implantation failure after in vitro fertilization (ICSI) and embryo transfer (IVF-ET), ${ }^{23}$ 
Patients having ICSI (IVF-ET) failure show an increased incidence of antiphospholipid (APL) antibodies, antiphosphatidyl serine (IgG-APS) and anti cardiolipin (IgG-ACL).These autoantibodies may be responsible for some IVF failures. (3)

Annexins are a family of structurally related proteins which all bind to anionic phospholipids (PLs) preventing clotting on vascular phospholipid surfaces.In humans the annexins are found inside the cell. However some annexins(Annexin Al, Annexin A2 and Annexin A5) have also been found outside the cellular environment in blood. ${ }^{(4)}$

Annexin A5 plays a role in the inhibition of blood coagulation by competing for phosphatidylserine binding sites with prothrombin and also to inhibit the activity of phospholipase Al also by competing for phosphatidylserine binding sites. (1)

Autoantibodies against annexin-V, a potent anticoagulant abundant in placental tissues, were reported to be associated with recurrent miscarriages or failures of in-vitro fertilization (IVF) attempts. (5)

Anticardiolipin Antibodies (ACL) are one of the antiphospholipid groups of antibodies. They are the most widely accepted and tested for immune factor. Approximately $80 \%$ of patients who have an antiphospholipid antibody problem will test positive for anticardiolipin antibodies, but the remaining $20 \%$ will test positive for one of the other antiphospholipid antibodies. (5)

\section{AIM OF STUDY}

To evaluate the role of anti-annexin $\mathrm{V}$ antibodies (aANX) and anticardiolipin antibodies (ACA) as predictors for in vitro fertilization-embryo transfer (ICSI) outcome.

\section{SUBJECTS \& METHODS}

This sludy was carried on 90 women with age ranging between $22-42$ years. They were referred from The Assisted Reproduction Unit of the International Islamic Centre for Population Studies and Researches of AI-Azhar University, Cairo, Egypt and The Health Centers in $10^{\text {th }}$ of Ramadan City.

Subjects were classilied into three groups:

Group I : Thirty women who had one or more failed in-vitro fertilization (ICSI)-embryo transfer despite good morphological quality of the transferred embryos.

Group II: Thirty non-pregnant women who had history of live births.

Group III: Thirty pregnant women (as controls) who delivered normally with no previous pregnancy losses.

* All cases were submitted to detailed history to exclude the presence of previous or recent blood; hepatic, renal, metabolic or gastrointestinal diseases which might affect the parameters 10 be investigated and they are non smokers.

* Complete medical examination and laboratory investigations were done to confirm the history and to exclude the presence of any autoimmune diseases e.g. systemic lupus, rheumatoid arthritis and infection, hypertension, diabetes mellitus etc.

\section{LABORATORY INVESTIGATIONS:}

Routine fasting and post-prandial blood glucose. serum triodothyronin (T3) and thyroxine (T4), serum prolactin, serum progesterone, serum antiannexin $V$ antibodies levels and serum anticardiolipin antibodies levels were performed for all subjects. Serum anti-annexin V Ig were measured by Eliza using Diapharma group Ins. ${ }^{(6)}$ Serum Anti-cardiolipin IgG by Eliza using IMMCO Diagnostics USA ${ }^{(7)}$

STATISTICAL ANALYSIS:

Data entry was done by using personal computer (Epi-Info Program) Range, mean + SD, 1 test, F test 
and correlation coefficionts were the statistical methods used in the analysis. $\mathrm{P}$ value $<0.05$ was considered as the level of significance,

\section{RESULTS}

Routine data in the studied groups were collected in table ( $\mathrm{I}$ ): fasting and post prandial blood sugar of all groups were found to be in the normal range, with no significant difference between the three groups. Serum triiodothyronine T3, serum thyroxine T4, prolactin and progesterone were also to be found within the normal range significant difference between the three groups. with no

Serum progesterone showed significant difference between group I \& III and also between group II \& III reflecting the physiological difference between the follicular phase of the menstrual cycle and early pregnancy.

Antiannexin- V (IgG): (Table II) (Fig.1): Serum anti-annexin - V IgG in group I was $9.6 \mu / \mathrm{ml}$ which means a highly significant increase when compared to the other two groups (II, III).

The serum antiannexin $V(\lg G)$ in group II was 1.2 $\mathrm{U} / \mathrm{ml}$. While in group III was $0.4 \mathrm{U} / \mathrm{ml}$ which mean that no significant difference between the two groups and the pregnancy control group (III) showed the lowest levels.

Anticardiolipin (IgG): (Table III) (Fig.2): Serum anticardiolipin ( $\mathrm{gG}$ ) in group I was $15.8 \mathrm{GPL} / \mathrm{ml}$ which means a highly significant increase when compared to the other two groups (II, III).

The serum anticardiolipin (gG) in group II was $2.07 \mathrm{GPL} / \mathrm{ml}$ while in the group III was 0.5 GPL $-\mu / \mathrm{ml}$ which means that no significant difference between the two groups.

Correlation coefficient ( $\mathrm{r}$ ) between anticardiolipin and antiannexin V (Table III). Correlation coefficient in group $\mathbb{I} 0.01$ and correlation coefficient in group II 0.00 , and correlation coefficieni in group III 0.00 . This indicates that, there is no correlation between anticardiolipin ( $\mathrm{ggG}$ ) and antianexin - $\mathrm{V}(\mathrm{Ig} G$ ) in all studied groups.

Table I : Mean and SD of measured routine data in the studied groups .

\begin{tabular}{|l|c|c|c|}
\hline & Group I & Group II & Group III \\
\hline FBS (mg/dl) & $77.9 \pm 6.2$ & $75.0 \pm 5.2$ & $77.2 \pm 6.4$ \\
\hline PPBS (mg / dl) & $101.1 \pm 9.6$ & $97.1 \pm 7.4$ & $101.0 \pm 8.6$ \\
\hline Serum T3 (ng/dl) & $124.2 \pm 22.01$ & $114.6 \pm 21.04$ & $122.06 \pm 18.3$ \\
\hline Serum T4 (ng/dl) & $7.9 \pm 1.1$ & $7.2 \pm 1.1$ & $7.7 \pm 1.2$ \\
\hline Serum prolactin (ng/dl) & $8.7 \pm 2.7$ & $8.09 \pm 2.3$ & $8.4 \pm 2.7$ \\
\hline Serum progesterone (ng/dl) & $0.5 \pm 0.2$ & $0.5 \pm 0.2$ & $29.3 \pm 8.5$ \\
\hline
\end{tabular}

FBS: Fasting blood sugat.

PPBS: Post-prandial blood sugar. 
Table II : Mean and SD of antiannexin- V (IgG) (U/mI) in the studied groups.

\begin{tabular}{|l|c|c|c|}
\hline & Group I & Group II & Group II \\
\hline Mean + SD & $9.6+2.1 \#$ & $1.2+0.8$ & $0.4+0.3$ \\
\hline Range & $7.5-19$ & $0.2-5.2$ & $0.0-1.3$ \\
\hline t & - & $20.0^{*}$ & $23.2^{* *}$ \\
P & - & $0.001^{*}$ & $0.001^{* *}$ \\
\hline t & - & - & $5.2^{* * *}$ \\
P & - & - & $0.001^{* * *}$ \\
\hline
\end{tabular}

* Between group I and II.

** Between group II and III.

*** Between group 1 and III.

N.B : Inspite of there is a significant statistical difference between group II, III but all the results lie in the normal ranges.

The table showed a significant statistically difference between group I and the other two groups.\#

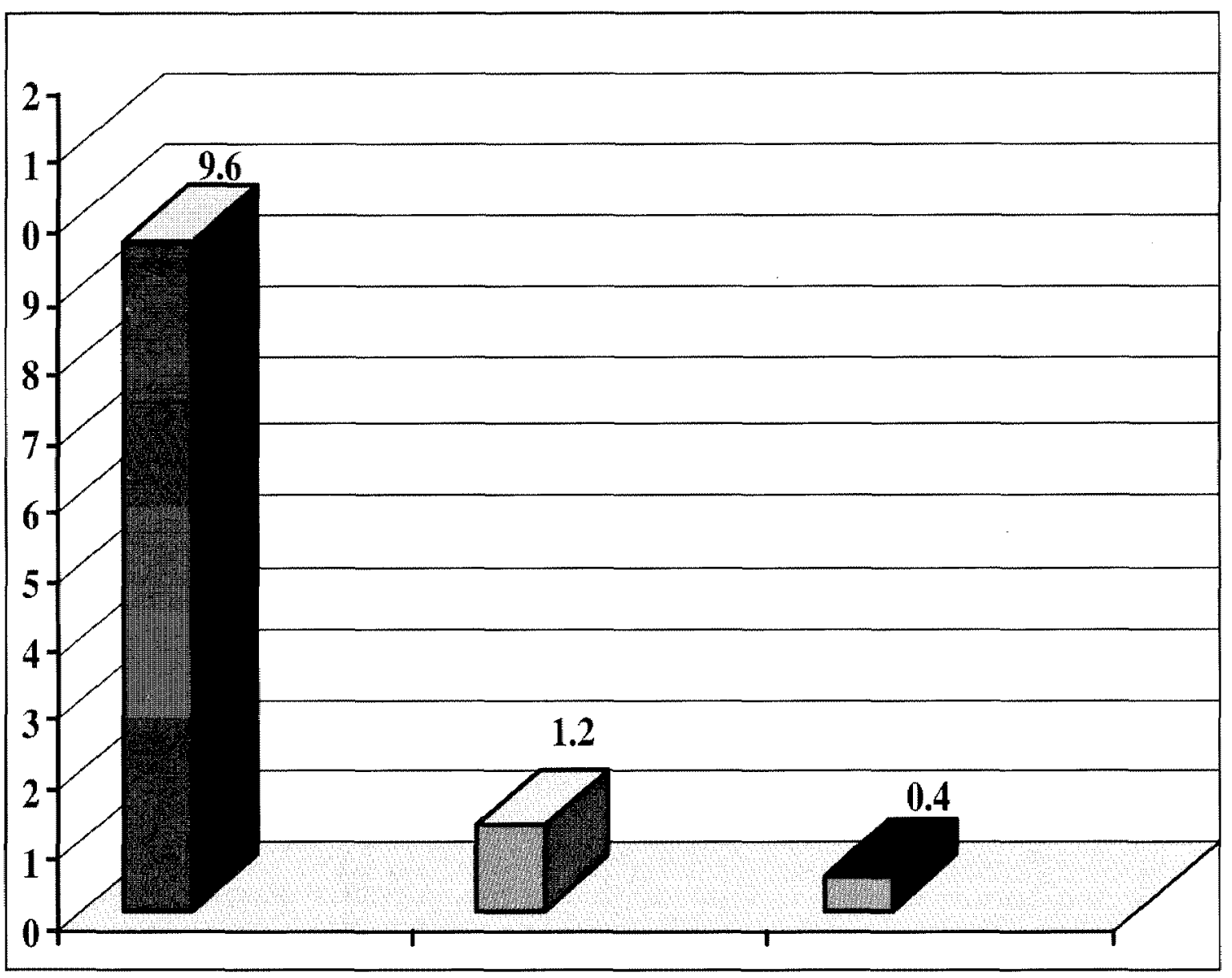

Fig. 1. Mean antiannexin in the studied groups. 
Table III : Mean and SD of anticardiolipin (IgG) (GPL/ml) in the studied groups.

\begin{tabular}{|l|c|c|c|}
\hline & Group I & Group II & Group III \\
\hline Mean + SD & $15.8+1.6$ & $2.07+1.02$ & $0.5+0.8$ \\
\hline Range & $13-20$ & $0.0-4.8$ & $0.0-4$ \\
\hline $\mathrm{t}$ & - & $39.3^{*}$ & $45.8^{* *}$ \\
$\mathrm{P}$ & - & $0.001^{*}$ & $0.001^{* *}$ \\
\hline $\mathrm{t}$ & & & $6.1^{* * *}$ \\
$\mathrm{P}$ & & & $0.001^{* * *}$ \\
\hline
\end{tabular}

* Between group I and II.

** Between group II and III.

*** Between group 1 and III.

N.B : Inspite there is a significant statistical difference between group II, III but all the results lie in the normal ranges.

The table showed a significant statistical difference between group I and the other two groups.

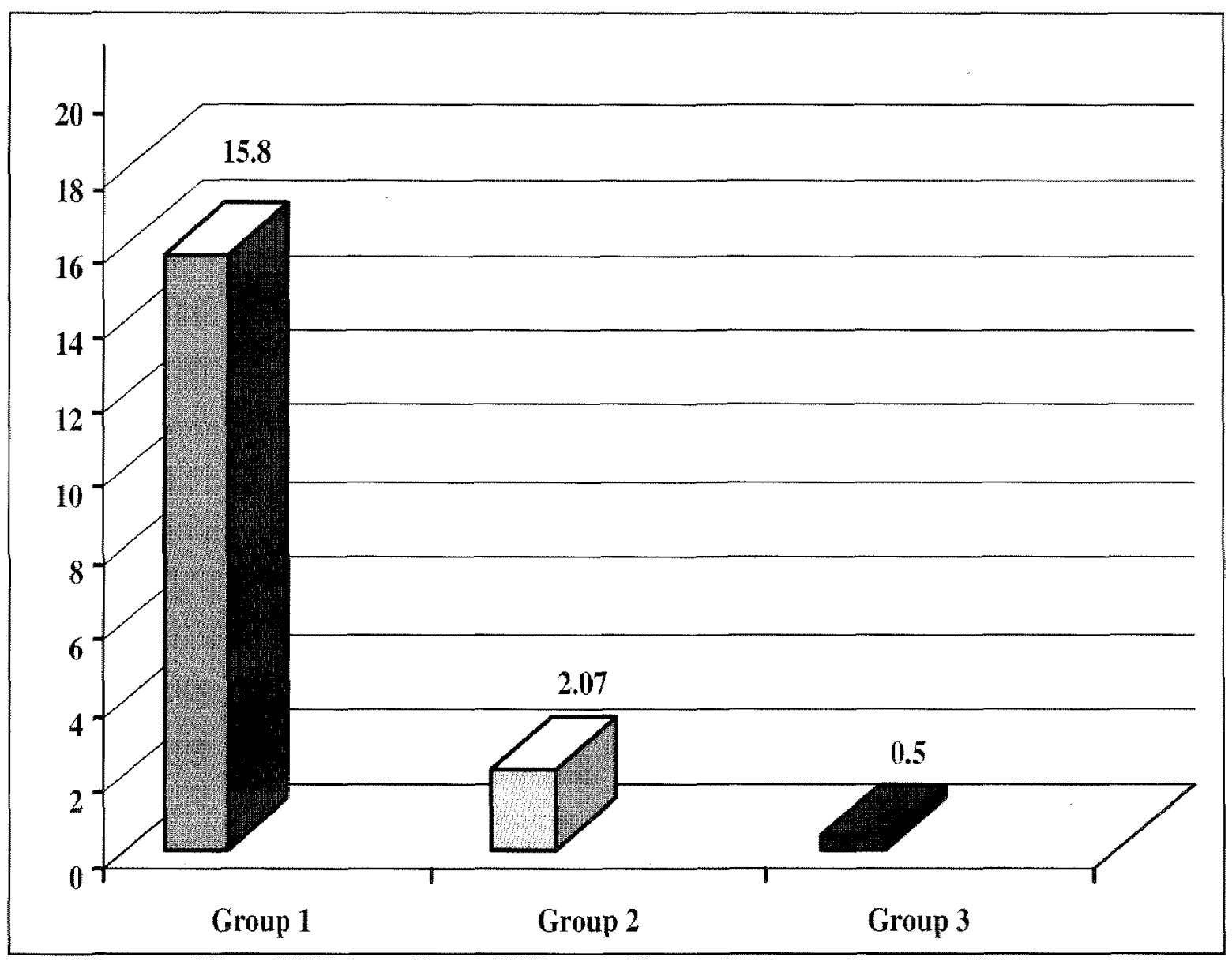

Fig. 2. Mean anticardiolipin in the studied groups. 
Table IV : Correlation coefficient ( $r$ ) between anticardio-lipin (IgG) and antiannexin-V (IgG) in the studied groups.

\begin{tabular}{|c|c|c|c|}
\hline Group & Coefficient & Std error & (r) \\
\hline I & -0.1 & 0.2 & 0.01 \\
\hline II & -0.03 & 0.1 & 0.00 \\
\hline II & -0.01 & 0.08 & 0.00 \\
\hline
\end{tabular}

\section{DISCUSSION}

Autoimmune abnormalities may be one of the possible causes for reproductive failure. The presence of abnormal, non pregnant specific autoantibody levels, i.e., anti-nuclear antibodies (ANA), anti-double stranded(ds) DNA, anti-cardiolipin antibodies (ACA), rheumatoid factor (RF), and lupus anti-coagulant (LAC) may result in a large variety of disorders; repeated pregnancy loss (9), endometriosis $(10)$, premature ovarian failure (11) ,unexplained infertility $(12)$ and repeated IVF-ET failure ${ }^{(13)}$.

Annexin $\mathrm{V}$ is a calcium-dependent protein that binds with high affinity to phosphatidyl serine-exposed during apoptosis ${ }^{(14)}$. Annexin $\mathrm{V}$ is a calcium-dependent phospholipids-binding protein that exhibits anticoagulant activity on binding to phosphatidyl serine exposed on the activated surfaces of endothelial cells and platelets, inhibiting activation of factor $\mathrm{X}$ and prothrombin in the blood coagulation cascade (15). The hallmark of the annexin super family of proteins is $\mathrm{Ca}^{+2}$ dependent binding to phospholipids bi-layers, a property that resides in the conversed core domain of these proteins (16). When PS is on the outer leaflet of acellular membrane it can support assembly of the prothrombinase complex ${ }^{(17)}$.
To prevent such assembly and subsequent thrombosis, Annexin V binds to PS on the villous syncytiotrophoblast to preclude such activity (18)

It has been postulated that annexin $\mathrm{V}$ forms an antithrombotic shield around the procoagulant anionic phospholipid phosphatidylserine on the trophoblast surface which precludes trophoblast participation in phospholipids dependent coagulation reaction (19). Trophoblast externalize Phosphatidyl serine in relation to differentiation -associated intercellular fusion, a necessary event for normal placental growth). (As a result of the normal role for PS externalization in trophoblast differentiation), Annexin $\mathrm{V}$ binding may be necessary for maintaining pregnancy $(20)$.

Our study demonstrates that women with recurrent IVF-ET failure (group I) showed a greater incidence of anti-ANX (IgG) antibodies than the other two groups, (group II non-pregnant women and group III pregnant women).Nonetheless, our data support the possibility that anti ANX is a risk factor for reproductive failure associated with IVF-ET failure. The Values in this study agreed with the values reported before by Matsubayashi et al., $2001^{(3)}$ who hypothesized that anti ANX might be involved in reproductive failure if by their presence the antithrombotic shield is compromised. Since 
annexin $\mathrm{V}$ had been described as forming a fetomaternal interface necessary to ensure successful pregnancy, their findings support the possibility that the presence of aANX is a potential risk factor for reproductive failure.

In an animal model, administration of Annexin $\mathrm{V}$ inhibited thrombus formation (21) and fibrin accretion ${ }^{(22)}$. Infusion of anti ANX decreased the availability of Annexin $\mathrm{V}$ to bind to the trophoblast surface, thereby causing placental thrombosis, necrosis, and fetal loss (23). These data support a pathogenic role for anti $\mathrm{ANX}$ in reproductive failure.

Our study is in contrast with only one study of Gris et al, $2000{ }^{(24)}$ who showed that anti ANX (IgG) is an independent risk factor of unexplained fetal loss between 10 and 24 weeks of pregnancy.

Interest has focussed also on the potential relationship between anticardiolipin antibodies and implantation failure after in vitro fertilization and embryo transfer (IVF-ET) ${ }^{(2)}$.

Our study had demonstrated that women with recurrent IVF-ET failure (group I) showed a greater incidence of ACL antibodies $(15.81 \mathrm{GPL} / \mathrm{ml})$ than the other two groups, (GROUP II) non-pregnant women $(2.07 \mathrm{GPL} / \mathrm{ml})$ and (GROUP III) pregnant women $(0.58 \mathrm{GPL} / \mathrm{ml})$. Values in this study agreed with the values reported before by the previous study published by Matsubayashi et al., 2001 (3).

Anti-cardiolipin has shown to bind embryo trophectoderm and to inhibit trophoblast proliferation and development ${ }^{(25)}$. Indeed, patients with aCL (IgG) in one IVF problem were found to have morphologically abnormal embryos. In addition, pre-implantation embryos derived from ACL-injected mice exhibited morphological(26) abnomalities and failed to implant to healthy recipients ${ }^{(27)}$. Other similar studies reported that women with IVFETfallures have an increased incidence (10 $32 \%$ ) of antiphospholipid (aPL) antibodies when compared with successful reproducing women or a normal population $(0-5 \%)^{(28)}$.

Our study contradicts the study of Chilcott et al. $2000^{(28)}$ who reported that despite of high prevalence of aPL in women referred for IVF, these antibodies do not inlluence the outcome of an IVF eycle. So Chilcott et al., $2000^{(28)}$ concluded that the routine screening of women undergoing IVF for aPL is not justified.

However ; as our study recommends ;Tan et al., $2005^{(29)}$ stated that ACL antibodies and lupus anticoagulant were the most frequent investigations suggested in recurrent IVF treatment failure in the UK followed by hysteroscopy then karyotyping. Antiphospholipid antibodies are an established cause of recurrent pregnancy loss, and defective embryonic implantation is a common link between unexplained infertility and recurrent miscarriage, So, Several investigators have advocated testing women undergoing in-vitro fertilization(IVF) for $\operatorname{APA}^{(30,31)}$ \& Serum Anti-cardiolipin Antibodies; Serum immunological factors may play a part in clinical pregnancy outcome in IVF-ET (29).

Antibodies to the negatively charged phospholipids and cardiolipin, has been reviewed by Rand et al, $1998^{(32)}$ and discussed by Rote et al. $1998^{(18)}$. They have reported that anti-pS or anti-cardiolipin can displace Annexin $V$ from the trophoblast surface and thereby expose procoagulant membrane sites to stimulate thrombosis. 


\section{REFERENCES}

1. Moss, S.E.; Morgan R.O. (2004): The annexins. Genome Biol; 5: 219. membranes and in culture media of placental villi. Am J. Ob stet. Gynecol., $177: 918-23$

2. Backos, M.; Rai, R. and Regan, L. (2002) : Antiphospholipd antibodies and infertility. Hum. Fertil. 5(1):30-4

3. Matusbayashi, H.; Arai, T; Izumi, S.; Sugi, T.; McInlyre, J.A. and Makno, T. (2001): Anti-annexin $V$ antibodies in patients with early pregnancy loss or implantation failures. Fertil Steril, 76:694-9.

4. Ulander, V.M.; Stefanovic, V.; Masuda,J.; Suzuki,K.; Hiilesmaa.V.; and Kaaja, R. (2007): Plasma levels of annexins IV and $\mathrm{V}$ in relation to antiphospholipid antibody status in women with a history of recurrent miscarriage. Thromb Res.120(6):865-70.

5. Halbmayer, W.M.; Feichtinger, W.; Kindermann, C.; Prendinger.B.; and Bohm. M. ( 2005): Recurrent miscarriage or failed in-vitro fertilization: antib odies against annexin $\mathrm{V}$, cardiolipin, beta-2-glycoprotein-1 and APC-resistance. Hamostaseologie; 25 (4): 391-393.

6. Nojima, J.M.; Kuratsune, H.; Suchisa, E.; Futsukaichi, Y.; Yamanishi, H.; Machii, T,; Iwatani, Y. and Kanakura, Y. (2001): Association between the prevalence of antibodies to beta (:2) -glycoprotein, prothrombin, protein C, protein 5, and annexin $V$ in patients with systemic lupus erythematosus and thrombotic and thrombocytopenic complications. Clin. Chem. 47(6): $1008-15$.

7. Lockshin, M.D.: Druzin, M.L. and Qamar, T. (1989): Predinsone does not prevent recurrent fetal death in women with antiphospholipid antibody. Am.
J.Obstet, Gynecol., $160: 439-443$.

8. Daniel, W.W.(1991): Biostatisties, a foundation for analysis in health science, 5th edition, New York New York, John Wiley.

9. Gleicher, N.: El-Roeiy, A.; Confino. E. and Fribreg. J. (1989): Reproductive failure because of auto-antibodies: Unexplained infertility and pregnancy wastage. Am. J. Obstet\& Gynecol., 160; $1376-1385$.

10. Gleicher, N.; EI-Roeiy, A. Confino, E. and Friberg, J. (1987): Auto-antibodies in reproductive failure: Is endometriosis an auto-immune disease? Obstet. Gynecol., 70:115-122.

11. La Borbera, A.R; Millre, M.M.; Obre, C. and Rebar, R.W. (1988) : Alltoimmune etiology in premalure ovarian failure. Am. 1. Reprod. Immunol., $16: 115-122$

12. Taylor, P. V.; Campbell, J.M. and Scot, J.S. (1989): Presence of auto-antibodies in women with unexplained infertility. Am. 1. Obstet. \& Gynecol., 161:377-379.

13. Stern, C.; Chamleyu, L.; Hale, L.; Kloss, M.; Speirs, A. and Baker, H. W.G. (1998): Antibodies to -2 glyco-protein I are associated with in vitro fertilization implantation failure as well as recurrent miscarriage: Results of a prevalence study. Ferti] Steril, $70 \cdot 938-944$

14. Glaser, M.; Collingride, D.R.; Aboagye, E.O.; Bouchier- Hayes, L.; Hutchinson, O.C.; Martin,S.J.; Price,Brady, F. and Luthra, S.K. (2003) : Iodine- 124 labeled annexin $V$ as a potential radiotracer to study apoptosis using positron emission tomography, Appl. Radiat. Isot. 58(1):55-62.

15. Ida, M.; satoh, A.; matsumoto, I. and Kojima-Aikawa, K. (2004): Human annexin V bind to sulfatide contribution to regulation of blood 
coagulation. $\mathbf{j}$. Biochem. 135(5):583-8.

16. Pael, D.R. Isas, J.M.; Ladokhin, AS. Jao, C.C.; Kim, Y.E.; Kirsch, T,iLangen, R. and Haigler, H.T. (2005): The conserved core domains of annexins $\mathrm{AI}, \mathrm{AZ}, \mathrm{As}$, and B12 can be divided into two groups with different $\mathrm{Ca}++$ dependent membrane-binding properties. Biochemistry, 44(8):2833-44.

17. Zwaal, R.F.A.; Comfurius, P. and Vandeenen, L.L. (1997): Membrane asymmetry and blood coagulation. Nature, 268:358-360.

18. Rote, N.S.; Bogt, E.; deVere, G.; Obringer, A.R. and $\mathrm{Ng} \mathrm{A-K} \mathrm{(1998):} \mathrm{The} \mathrm{role} \mathrm{of} \mathrm{placental} \mathrm{trophoblast} \mathrm{in}$ the pathophysiology of the antiphospolipid antibody syndrome. Am. J. Reprod. Immuno. 39: 125-36.

19. Rand, J.H.: Wu, X.X.; Guller, S.; Scher, J.; Andree, A.A.M. and Lockwood, C.J. (1997): Anti-phospholipids immunoglobin $G$ antibodies reduce annexin $\mathrm{V}$ levels on syncytiotrophoblast apical

20. Obringer, A.R.; Dean, K.W., Channel, S.R. and Rote, N.S. (1997): Aminophospholipid irnaslocase activity in JEG-3; a choriocarcinoma model of cytotrophoblast differentiation. Placenta, 18:421-6.

21. Romisch, 1.; Seiffge, D.; Reiner, G.; Paques, E.P.; Heinburger, N. (1991): In vivo antithrombotic potency of placenta protein 4 (annexin V). Thromb. Res., 61:93-104.

22. Ryn-McKenna, J. V.; Merk, H.; Muller, T.H.; Buchanan, M.R. and Eisert, W.G. (1993): The effects of heparin and annexin $\mathrm{V}$ on fibrin accretion after injury in the jugular veins of rabbits. Thromb. Haemost., 69:227-30.

23. Wang, X.; Campos, B; Kietzel, M.A. and Deman, J.R. (1999): Annexin V is critical in the maintenance of murine placental integrity. Am. J. Ob stet. Gynecol. I80: 1008-J 0 16.
24. Gris, J.C.; Quere, 1.; Simmarco, M. ; Boutere, B. Mercier, E.; Aminal, J.; Hubers, A.M.: Ripart-Neveu, S.; Hollet, M.; Yailland M.L.; Rousseau. O. Monpeyroux, F.; Dauzat, M.; Sampol, J.; Daures, J.P.; Berlan, J. and Mares, P. (2000): Antiphospholipid and antiprotein syndromes in nonthrombotic, non-autoimmune womer with unexplained recurrent primary early foetal loss. The Nimes Obstetricians and Haematologists Study NOHA. Thromb Haemost., 84(2): 228-36.

25. Sthoeger, ZM.: Mores. E. and Tartakorsky. B. (1993) : Anti-cardiolipin antibodies induce pregnancy failure by impairing embryonic implantation. Proc. natl. Acad. Sci., 90:6464-6467.

26. Azem, F.; Geva, E.; Amit, A.; Lerner-Geva, L.; Swartz, T.; Ben- Y osef, D; Y ovel, I. and Lessing J.B. (1998) : High levels of anti cardiolipin antibodies in patients with abnormal embryo morphology who attended an in vitro fertilization program. Am. J. Reprod. Immunol.,39:16 - 163.

27. Tartakorsky, B.; Bermas, B.; Sthoeger, Z. et al. (1996) Defective maternal-fetal interaction in a murine autoimmune model. Hum. Reprod., 11, $2408-2411$

28. Chileott, LT; Margara.. R.; Cohen, H.; Rai, R; Skull, J.; Pockering, W. and Regan, L. (2000): Pregnancy outcome is not affected by antiphospholipd antibody status in women referred for in vitro fertilization. Fertil Steril, 73:526-530.

29- Tan, B.K.; Vandekerchkhove, P.; Kennedy, K. and Keay, S.D. (2005): Investigation and curtent management of recurrent IVF treatment failure in the UK. BJOG, 112(6):773-80

30-Gleicher, N.; Liu, H.; Dudkiewicz, A. et al (1994): Auto-antibody profiles and immunoglobulin levels as predictors of IVF success. Am. J. Obstet. Gynecol., 170,1145-1149. 
31- Birdsall, M.A.; Lockwood, G.M.; Ledger, W.L. et al. (1996): Antiphospholipid antibodies in women having in vitro fertilization., Hum. Reprod., 11,1185-1189.

32- Rand, J.H.; Wu, X.X.; Andree, A.A.M.;
Alexander, Roos, J.B.; Rusinova, E.; Gascon-Lema, M.G. et al. (1998): Antiphospholipid antibodies accelerate plasma coagulation by inhibiting annexin$\mathrm{V}$ binding to phospholipids a "lupus procoagulant: phenomenon. Blood, 92:1652-60. 